\title{
Timing of speleogenesis of Las Karmidas Cave (Mexico): first description of pseudokarst developed in ignimbrite
}

\author{
María del Pilar Aliaga-Campuzano ${ }^{1}$, Rafael López-Martínez ${ }^{2}$, Pablo Dávila-Harris ${ }^{3}$, \\ Ramón Espinasa-Pereña ${ }^{4}$, Adriana Espino del Castillo ${ }^{5}$, and J. P. Bernal ${ }^{*}$ \\ ${ }^{1}$ Laboratorio de Estudios Isotópicos, Centro de Geociencias, Universidad Nacional Autónoma de México, Campus Juriquilla, Querétaro, 76230, Mexico \\ ${ }^{2}$ Laboratorio de Carbonatos y Procesos Kársticos, Instituto de Geología, Universidad Nacional Autónoma de México, Ciudad Universitaria Campus, \\ Coyoacán, C.P. 04510, Mexico City, Mexico \\ ${ }^{3}$ División de Geociencias Aplicadas, Instituto Potosino de Investigación Científica y Tecnológica, A.C. 78216, San Luis Potosí, Mexico \\ ${ }^{4}$ Centro Nacional de Prevención de Desastres (CENAPRED), Mexico City, 04630, Mexico \\ ${ }^{5}$ Departamento de Procesos y Tecnologia, División de Ciencias Naturales e Ingeniería, Universidad Autónoma Metropolitana, Cuajimalpa, Mexico
}

\begin{abstract}
Las Karmidas Cave (Puebla State, Mexico) is an unusual type of pseudokarstic cavity generated by piping and erosive processes within the contact of a diamicton and an overlying Quaternary ignimbrite. Morphological evidence suggests that the cave was developed in two stages: a phreatic stage and a vadose stage. The latter was characterized by the formation of carbonate speleothems. The absolute upper-age limit for the cave $(168+7.1 /-7.5 \mathrm{ka})$ was established by U-Th dating of zircons grains extracted from the overlying ignimbrite, whilst a minimum age for the transition from a phreatic to vadose regime (95.6 $\pm 2.1 \mathrm{ka})$ was constrained by U-Th dating of carbonate speleothems within the cave. The geochronological results indicate a very rapid evolution of this pseudokarstic system, and suggest that similar systems might evolve and degrade at a very fast pace; consequently, making them hard to be preserved. Despite this, and considering the rather common geological context in which this system was developed, it is likely that similar pseudokarstic systems are yet to be detected worldwide.
\end{abstract}

Keywords: $\quad$ pseudokarst, cave, speleogenesis, Xaltipan ignimbrite, Las Karmidas Cave

Received 1 December 2016; Revised 5 April 2017; Accepted 6 April 2017

Citation: $\quad$ Aliaga-Campuzano M.P., López-Martínez R., Dávila-Harris P., Espinasa-Pereña R., Espino del Castillo A. and Bernal J.P., 2017. Timing of speleogenesis of Las Karmidas Cave (Mexico): first description of pseudokarst developed in ignimbrite. International Journal of Speleology, 46 (3), 331-343. Tampa, FL (USA) ISSN 0392-6672 https://doi.org/10.5038/1827-806X.46.3.2097

\section{INTRODUCTION}

Pseudokarst processes and geoforms have been recently recognized as an important source of landscape modification (Benson \& Yuhr, 2016). Despite its ubiquitous occurrence and relevance in geomorphic and geotechnical studies, the formation of pseudokarstic caves where mineral solution is not the driving force modulating cave development, remains to this day poorly understood (Wray, 1997; Doerr \& Wray, 2004; Halliday, 2007). Different terminology has been proposed for such non-dissolution caves, based on rock or processes involved (Halliday, 2007; Eberhard \& Sharples, 2013). However, some caves fail to fit any of these descriptions as they were formed by more than one process, and within different lithologies.

A better understanding of pseudokarstic processes can be obtained by applying a multidisciplinary approach that can provide links between stratigraphy, sedimentary facies, and establish geochemical and geochronological constraints on the origin, timing and/or rates of deposition of the different materials. Unfortunately, most pseudokarstic systems display poor conservation of structures, sediments, and passage morphology, and, notably, a systematic lack of authigenic minerals amenable for radiometric dating.

Here, we describe for the first time the Las Karmidas Cave, an extraordinary study site in southern Mexico, characterized by its emplacement at the contact between a diamicton and an ignimbrite, as well as the presence of carbonate speleothems in the cave passages. Because of its well preserved sedimentological structures, we are able to propose an evolution model based on piping and erosion. Moreover, by applying U-Th zircon dating methodologies by LA-MC-ICPMS, we are also able to establish robust geochronological constrains on the evolution and formation of the cave. 


\section{CAVE LOCATION AND GEOLOGICAL SETTING}

Las Karmidas Cave (200' 20” N 97 42' 53” W, 700 m.a.s.1.) is located at Zapotitlán de Méndez, Puebla, Mexico (Fig. 1A, B). The oldest formations exposed in the surrounding areas are manly Jurassic and Cretaceous shale and limestone. These formations include: Huayacocotla (Jhx), Cahuasas (Jcs), Tepexic (Jtx), Santiago (Jsg), Tamán (Jt), Pimienta (Jp), Lower Tamaulipas (Kti), Upper Tamaulipas (Kts), and Agua Nueva (Kan) (López-Ramos, 1979; López-Ramos, 1982) (Fig. 1C, D). These units comprise mainly marine basin and platform sediments, folded and thrusted during Sevier and Laramide orogenies, to conform the Mexican fold and thrust belt (Dickinson \& Lawton, 2001; Gray et al., 2001). Towards the south of Zapotitlán de Méndez, the abrupt topography developed on the Mesozoic lithology was covered by a succession of Cenozoic volcanic materials (andesite lava), lacustrine sediments and vast Quaternary volcanic units such as basaltic lava flows and felsic tuffs. Volcaniclastic and epiclastic successions are also commonly exposed in valley bottoms (LópezRamos, 1982; Capra et al., 2003). The study area is also near a well-studied volcanic field, the LibresOriental basin, which belongs to the eastern part of the Transmexican Volcanic Belt (TMVB) (Lugo-Hubp et al., 2005; Siebe et al., 2006; Alaniz-Álvarez \& NietoSamaniego, 2007; Norini et al., 2015).

The Libres-Oriental basin volcanic field is limited on the east by the large $(21 \times 16 \mathrm{~km})$ Los Humeros Caldera (Ferriz, 1984; Campos-Enriquez \& GarduñoMonroy, 1987; Carrasco-Núñez \& Branney, 2005), which is located $45 \mathrm{~km}$ southeast of Zapotitlán de Méndez (Fig. 1A). After rhyolite dome eruptions a paroxysmal event originated the Xaltipan ignimbrite (Ferriz, 1984), which produced an enormous collapse caldera and more than $115 \mathrm{~km}^{3}$ of pyroclastic flows emplaced radially around the volcano. These partially filled surrounding ravines for tens of kilometers around the caldera, including the already deep valleys of both the Apulco and Zempoala rivers (Ferriz, 1984; Ferriz, 1985; Ferriz \& Mahood, 1987; Carrasco-Núñez et al., 2012; Norini et al., 2015). This ignimbriteforming eruption generated a valley fill which has been progressively incised by river erosion, leaving low and hanging terraces at both valley sides, very prone to landsliding (López-Ramos, 1982; YañezGarcía \& García-Durán, 1982; Ferriz \& Mahood,
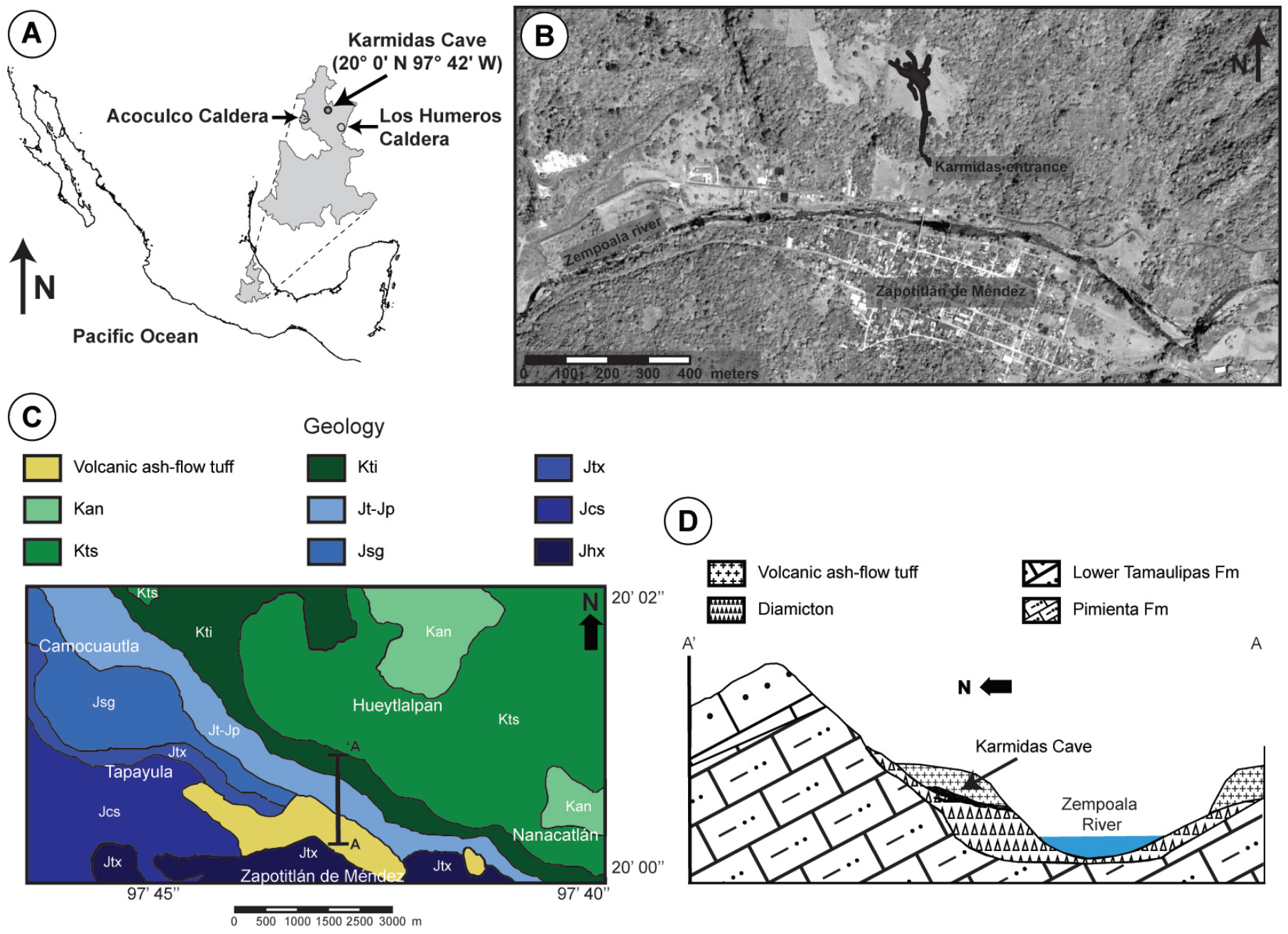

(D)
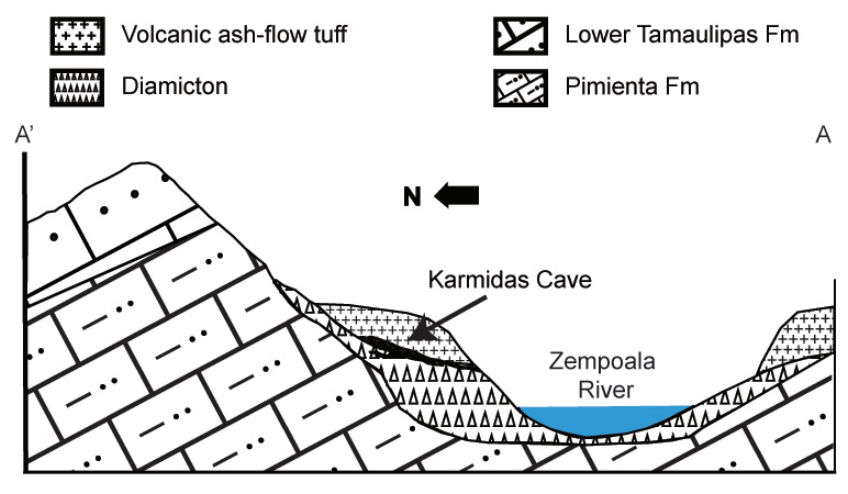

Fig. 1. A) Location of Las Karmidas Cave in the state of Puebla, Mexico and the the two main calderas in the vecinity of Zapotitlán de Méndez; B) Aereal view of Zapotitlán de Méndez, the Zempoala River and an overlaping image of the cave to show the location inside the hill were Las Karmidas Cave developed; C) Geological formations around Zapotitlán de Méndez. Mesozoic units: Huayacocotla (Jhx), Cahuasas (Jcs), Tepexic (Jtx), Santiago (Jsg), Tamán (Jt) and Pimienta (Jp). Cretaceous units: Tamaulipas Inferior (Kti), Tamaulipas Superior (Kts) and Agua Nueva (Kan). Quaternary: rhyolitic ignimbrite. Modified from Hernández (2008). The entrance of the cave is located at the base of a hill on the northwest valley side nearby Zapotitlán de Méndez Village; D) Schematic chart of the geological section at the location of the cave. In black is shown the location of the cave within the diamicton and the rhyolitic ignimbrite. 
1987; Capra et al., 2003; Lugo-Hubp et al., 2005). The Los Humeros Caldera continued erupting explosively until the Holocene (Dávila-Harris \& Carrasco-Núñez, 2013), although no eruption has been as catastrophic as the one which produced the Xaltipan ignimbrite (Norini et al., 2015).

\section{METHODS}

\section{Cave mapping and facies analysis}

Underground mapping inside the cave was carried out using compass, clinometers, and tape measure for a UISv1-4-3-A as suggested by Häuselmann (2011). Characteristic features including ponds, waterfalls, rockslides, springs, main galleries, speleothems, and the man-made entrance are indicated in Fig. 2 (map \& section). A schematic cross section was also produced with $2 \mathrm{x}$ vertical exaggeration, indicating location of main features within the cave, to which we will refer throughout this work. Sample points and other characteristics are also featured in the map and cross section of the cave. Sedimentary facies were classified into diamicton, thalweg, backswamp, channel, and slackwater facies according to the classification of Bosch \& White (2004).

\section{Geochemistry and geochronology}

Pumice samples (Supplemental Table 1) collected at a quarry $\left(20^{\circ} 00^{\prime} 20.95^{\prime \prime} \mathrm{N} 97^{\circ} 43^{\prime} 28.68^{\prime \prime} \mathrm{W}\right)$ near the town of Zapotitlán de Méndez, hereafter Zapotitlán Quarry, were analyzed for major elements. Analysis was performed using a WD-XRF on Li-borate/ metaborate fused disk following the methodologies of Lozano \& Bernal (2005), and trace elements, rare earth elements (REE), using ICP-QMS following Eggins et al. (1997), using BHVO-1, RGM-1, GSR-2 and SDO-1 as calibration standards and the compositions reported by Govindaraju (1994). Both analyses were conducted at the Instituto de Geologia, UNAM. Precision and accuracy were assessed by multiple analysis of inhouse reference sample IGLa-1 (Lozano \& Bernal, 2005). In general, accuracy is better than $95 \%$ for major elements, and $90 \%$ for trace elements.

To establish geochronological constrains on the deposition of the ignimbrite, thus the emplacement rock hosting the cave, zircons were extracted from samples collected at the Zapotitlán Quarry using standard heavy-mineral extraction techniques, and dated using U-Th systematics (Schmitt, 2011). Additionally, to verify the age and origin of the ignimbrite, zircons from a sample collected at Las Minas, Puebla $\left(19^{\circ} 41^{\prime} 32^{\prime \prime} \mathrm{N}\right.$ $97^{\circ} 8^{\prime} 57^{\prime \prime} \mathrm{W}$ ), which is generally recognized to be part of the Xaltipan ignimbrite (Ferriz \& Mahood, 1984), were also analyzed. U-Th dating of zircons (Supplemental Table 2) was carried out using a Neptune-plus MCICP-MS coupled to a Resonetics L-50 laser-ablation workstation (Müller et al., 2009; Solari et al., 2010) following the methodology of Bernal et al. (2014). Precision and accuracy was continuously assessed by analyzing two zircon samples known to be at secular equilibrium: standard zircon 91500 with a U/Pb age $=1,065 \pm 0.6 \mathrm{Ma}$ (Wiedenbeck et al., 2004), and our laboratory internal standard, Panchita zircon, with an $\mathrm{U} / \mathrm{Pb}$ age $=959 \pm 1.4 \mathrm{Ma}$, which are expected to be in

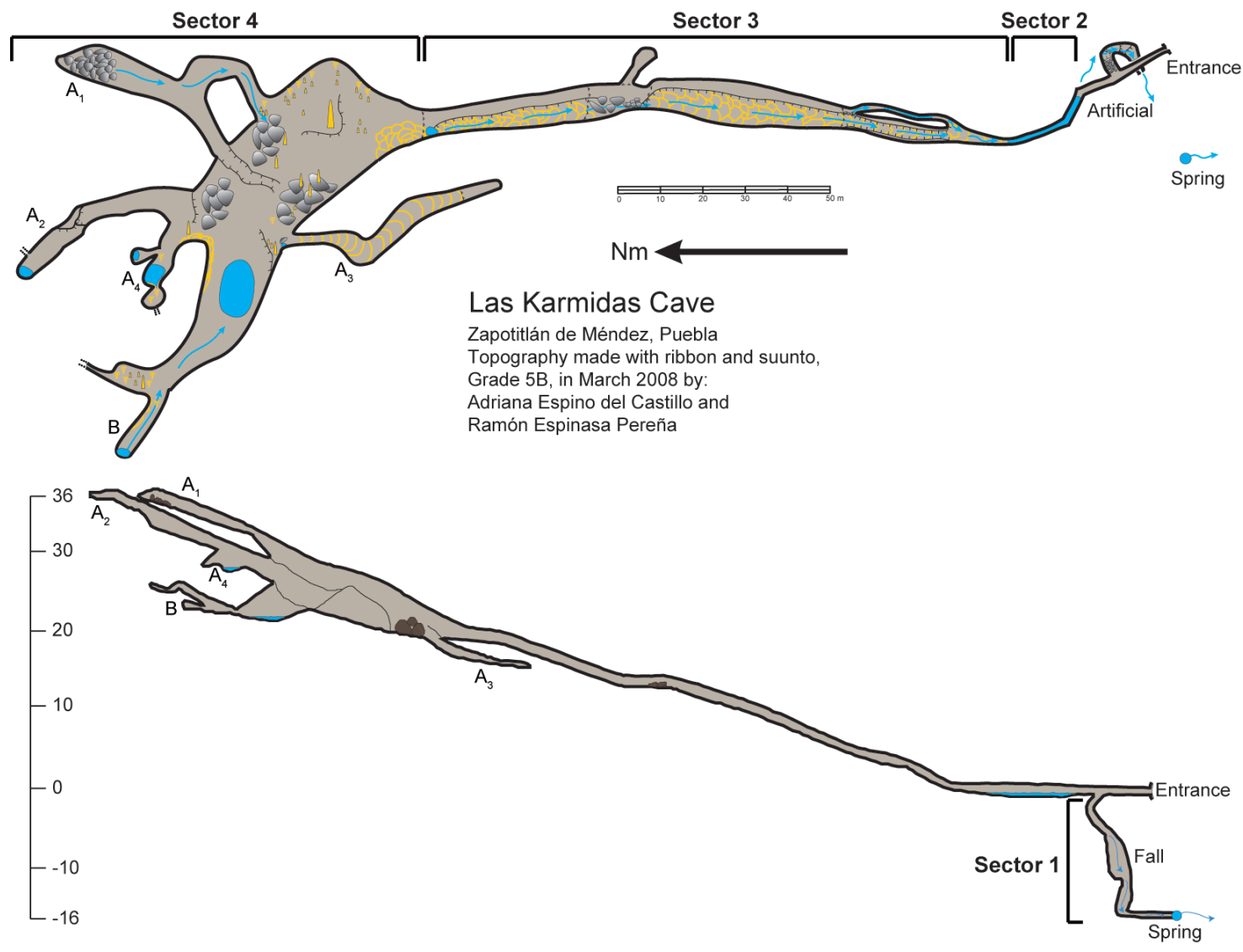

Fig. 2. Top: Map of Las Karmidas Cave. Bottom: Schematic cross section with $2 x$ vertical exaggeration. Characteristic features such as ponds (blue), waterfalls (blue arrows), rockslides (grey semicircular shapes), man-made entrances, springs (dot with blue arrow), main galleries, and speleothems (yellow triangle-like shapes) are indicated. The sectors described in the cave morphology section are also shown here. 
secular equilibrium, i.e., $\left({ }^{230} \mathrm{Th} /{ }^{238} \mathrm{U}\right)=1.00$; note that all ratios between brackets represent activity ratios. Results from more than 400 independent analyses for each zircon obtained, during 20 different analytical sessions, attest to the long-term high-reproducibility and precision of the methodology used here, with $\left({ }^{230} \mathrm{Th} /{ }^{238} \mathrm{U}\right)=1.0006 \pm 0.0031(2 \mathrm{xSE}, \mathrm{n}=370, \mathrm{MSWD}$ $=1.105)$ for 91500 zircon, and $\left({ }^{230} \mathrm{Th} /{ }^{238} \mathrm{U}\right)=1.005 \pm$ $0.0022(2 \mathrm{xSE}, \mathrm{n}=340, \mathrm{MSWD}=2.05)$ for Panchita zircon. The ${ }^{238} \mathrm{U} /{ }^{232} \mathrm{Th}$ and ${ }^{230} \mathrm{Th} /{ }^{232} \mathrm{Th}$ composition of the magma was estimated from the $U$ and $T h$ concentrations obtained from the whole-rock ICPMS analysis, assuming secular equilibrium (i.e., $\left.{ }^{230} \mathrm{Th} /{ }^{238} \mathrm{U}=1.00 \pm 0.05\right)$ (Schmitt, 2011).

Carbonate samples from the cave (Supplemental Table 2 in electronic supplement) were dated by isotope-dilution MC-ICPMS, using a ThermoFinnigan Neptune Plus at Centro de Geociencias, UNAM, following methodologies described elsewhere (McCulloch \& Mortimer, 2008; Hernández-Mendiola et al., 2011). For zircon and carbonate dating, U-Th activity ratios and ages were calculated using the half-lives from Jaffey et al. (1971) Audi et al. (1997); Cheng et al. (2013) for ${ }^{238} \mathrm{U},{ }^{232} \mathrm{Th},{ }^{230} \mathrm{Th}$, and ${ }^{234} \mathrm{U}$, respectively. Isochrons and age-calculations were carried out using Isoplot 3.75 (Ludwig, 2012).

\section{RESULTS AND DISCUSSION}

\section{Cave Stratigraphy}

The general stratigraphy of the cave (Fig. 3) begins with (a) a Quaternary diamicton (fines-rich talus breccia) that unconformably rests upon unexposed Mesozoic carbonate rocks (Fig. 1D), followed by (b) a Quaternary rhyolitic ignimbrite, in both welded and non-welded facies (Fig. 4A); (c) an heterolithic breccia that post-dates the ignimbrite, and (d) Holocene unconsolidated sand, silt and clays. Detailed stratigraphic logs through the internal units were used to describe the local stratigraphic relationships.

Diamicton: It is a brown, massive and matrixsupported unconsolidated to poorly consolidated deposit formed by sub-angular blocks of limestone, shale and scarce volcanics, supported in a clayey to silty matrix (Fig. 4B). It is at least $5 \mathrm{~m}$ thick, massive and non-stratified. The upper contact of the diamicton is sharp and in places shows a slight pink color change that resembles a 'baked' contact by the overlying volcanic unit (Fig. 3). It is interpreted as formed by talus, slope or local cohesive debris-flow events, due to the abrupt local topography.

Quaternary rhyolitic ignimbrite: Lies directly and unconformably above the diamicton (Fig. 4C), as a pale-cream to grey, non-welded tuff to lapilli-tuff. The contact can be clearly observed at the manmade entrance to the cave. The tuff preserves a minimum thickness of 3 to $50 \mathrm{~m}$ near and within the cave, but with thicker exposures (near $200 \mathrm{~m}$ ) at the outskirts of Zapotitlán de Méndez. The base of the tuff is finely laminated to cross-laminated, with thin lithic trails and sporadic larger lithic clasts protruding. It grades upwards into a massive pumice and lithic poor lapilli-tuff. The material that forms the tuff matrix is mainly rhyolitic glass shards needles and ash (Fig. 4D); lithic clasts and phenocrysts are scarce but include quartz, biotite, feldspar and plagioclase. The juvenile component is represented by altered, rounded and slightly fibrous rhyolitic pumice lapilli, relatively crystal-poor. Lithics include limestone, shale, andesite, basalt and rhyolite. The tuff contains lateral and vertical facies changes (Fig. 5), the most contrasting one is exposed at the narrowflooded entrance, where the welded facies can be observed, resembling a vitric tuff with spherulites and lithophysae (devitrification) structures and fiamme-like pumices. Under the microscope, eutaxitic texture is clearly defined within this lithofacies. Per these features, this unit, which postdates the diamicton, is defined as a variously welded, rhyolitic pyroclastic flow deposit (ignimbrite), that would have infilled the Zempoala River valley at the time of its emplacement; from which only eroded terraces are preserved today. The geomorphology of the region is in an active stage and the remains of the ignimbrite are prone to landslides due to the unconsolidated nature of the material (Capra et al., 2003; Lugo-Hubp et al., 2005; Hernández, 2008).

Breccia: This unit is exposed at the cave ceiling and is placed unconformably above the ignimbrite (Fig. 4E). It is a heterogeneous deposit formed by large, angular clasts in a lithic-rich matrix. The breccia presents an erosive lower contact, either formed by scours and channels or just sharp fractured contacts. Its lithology comprises limestone and shale blocks and large clasts from the underlying welded and non-welded tuff. It is mainly massive and ungraded, although showing levels of finer grained sediments. This unit is interpreted as a locally-derived collapse breccia of the upper parts of the cave, and suggests that parts of the cave ceiling might have collapsed at least once, during the cave's evolution.

Detrital cave facies: The youngest deposits inside the cave comprise a succession of fine-grained, brown silts and sands that range from 0.5 to $4 \mathrm{~m}$ thick (Fig. 4F). This unit rests unconformably on top of the cave walls, unconformably over the diamicton, the ignimbrite and locally on top of the breccia (Fig. 3). They comprise thalweg, channel, slack water, and backswamp facies. Although this unit has not been directly dated, it is considered a continuous deposit which could be Holocene in age.

Thalweg (TW): Formed by well-winnowed material, mainly boulders and some cobble; the majority of the fragments are ignimbrite and, in less quantity, limestone. This facies sensu Bosch \& White (2004) is the result of the winnowing of the fine material of the diamicton and collapses, remaining only the coarse sediments.

Channel facies $(\mathrm{CH})$ : Are mainly composed of limestone and ignimbrite fragments embedded within a sand to gravel matrix. Imbrication and cross bedding in a chaotic fabric are the most common sedimentary structures.

Slack-water facies (SLW): Fine grained clays and silts with parallel lamination. These facies appear almost horizontally in the upper part of the sequence. 

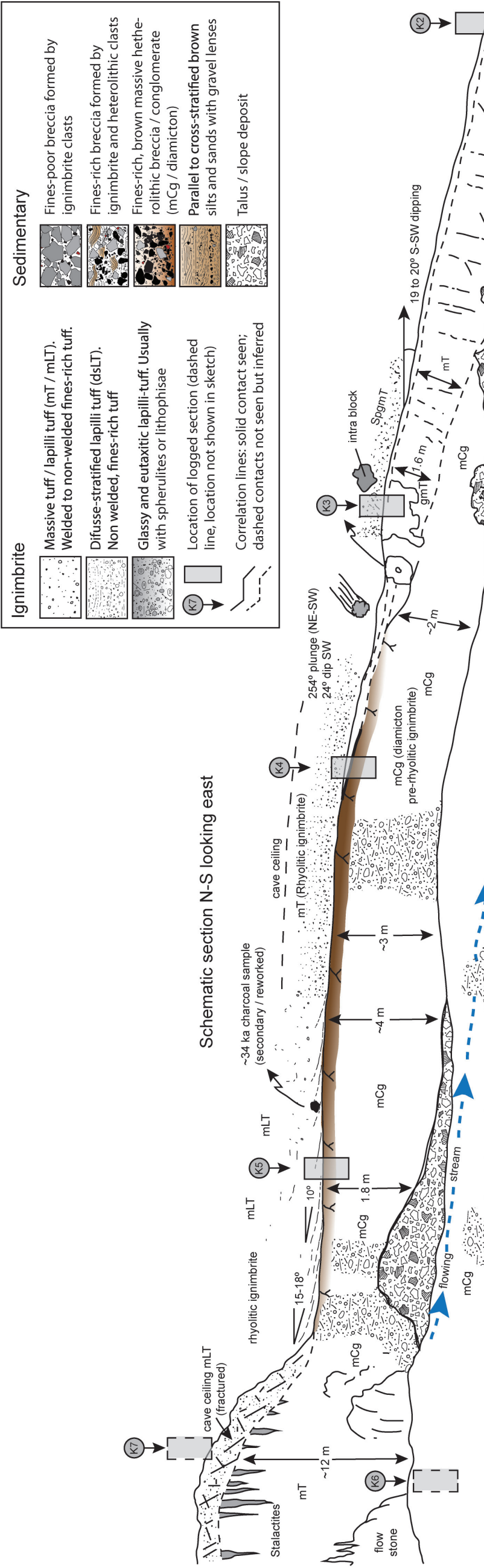

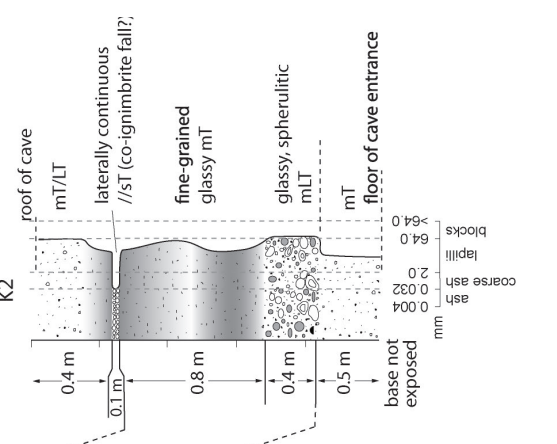

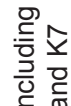

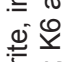

हैं

흥

긍

르ㄴㅡㅡ

竞离

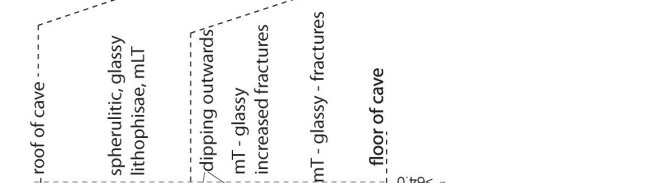

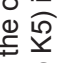

응

कo

ह 을

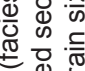

등

흐응

车

बํ.

券要

葸告

잉

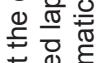

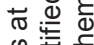

당

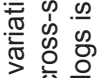

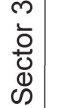

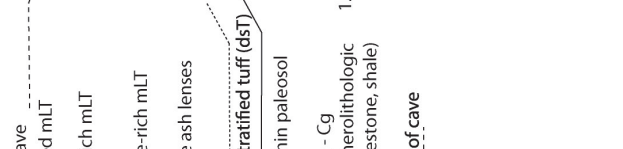

可政

응 홍 웡

至要

践

․ㅡㅇ

需

定

c.

ठำ

का है क

颉

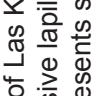

要卷

올

을

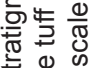

के

도월

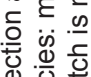

क .

o क

ह

फ

ल

원뽀 

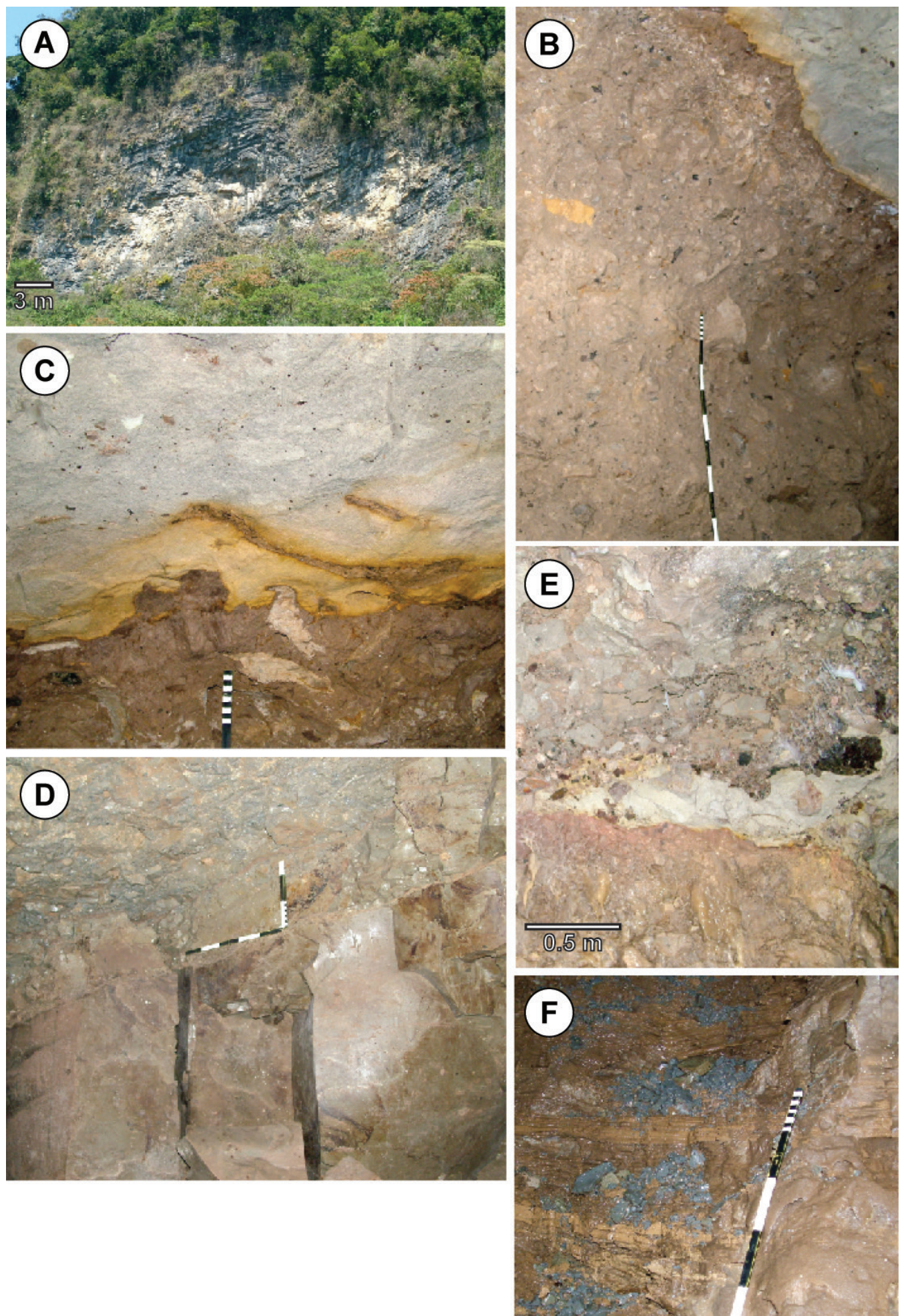

Fig. 4. Main lithologies at Las Karmidas Cave: A) Mesozoic basement formed by folded carbonate rocks (limestone, marls, shale); B) Diamicton in a clayey matrix, note direct contact with the non-welded tuff;

C) Sharp unconformable contact between the diamicton and the ignimbrite, notice white pumice clasts;

D) Welded facies of the ignimbrite, exposing columnar joints and devitrified levels (entrance of cave);

E) Local breccia inside the cave; F) Post-cave Holocene laminated flood sediments (silts and clays).

Scale bar is $1 \mathrm{~m}$ with $10 \mathrm{~cm}$ intervals.

Backswamp facies (BSW): Composed of clays, with no clear stratification or any other sedimentary structures.

\section{Cave geomorphology by sectors}

Sector 1: waterfall and spring

Sector 1 in Fig. 2 consists of a narrow and very low passage (Fig. 5A), which becomes wider at the base of a small waterfall of $\sim 12 \mathrm{~m}$ (Fig. 5B). Beyond the waterfall, the passage becomes smaller again until joining the artificial entrance (Fig. 5C). The sediments here are a succession of thalweg, channel and slackwater deposits, covered and cemented by flowstones (Fig. 5D).

At least one level of horizontal thalweg-channel facies points to a paleoflood that completely filled the conduit (Fig. 5E). Later, these deposits were eroded and a new lower conduit was formed. All sediments are cemented by relatively more recent flowstones (Fig. 5A, B). 



Fig. 5. Morphology at sector 1. A) Narrowed passage at top of the sector; B) Waterfall of $\sim 12 \mathrm{~m}$; C) Narrow passage passed the waterfall; D) The sediments sector 1 are a succession of thalweg, channel and slackwater deposits; covered and cemented by flowstone; E) Paleoflood that covered the conduit.

\section{Sector 2}

Sector 2 in Fig. 2 is a curved passage carved within the rhyolitic tuff. All along this sector there is a continuous flow of water, which is sensitive to rain variability outside the cave. Here, water flux often blocks the passage during the peak of the rainy season (August-September), particularly when hurricanes reach the area.

\section{Sector 3}

Sector 3 in Fig. 2 is characterized by a rectilinear steep tunnel with a $\mathrm{N} 0-10^{\circ} \mathrm{E}$ direction. In cross section, the passage shows keyhole morphology (Fig. 6A), indicating a two-stage formation: phreatic, evidenced by an elliptical cross section elongated in the direction of the diamicton/ignimbrite contact, which was followed by a vadose erosive stage incising the diamicton. Additionally, this sector presents some tributary phreatic conduits with circular cross section and orientated in the direction $\mathrm{S} 50^{\circ} \mathrm{E}$ (Fig. 6B). Channel, thalweg and slack water facies deposits are present in this sector (Fig. 6C, D), covered by flowstone, suggesting abundant sediment supply, followed by an abrupt change in deposition conditions that allowed the precipitation of calcite with significantly less clastic sediment contribution (Fig. 6E, F).

\section{Sector 4}

This sector is the widest part of the cave, $\sim 30 \mathrm{~m}$, produced by the junction of three different streams (Fig. 2). This chamber formed mostly by erosion of the diamicton, as evidenced by the nearly flat roof at the inception horizon (the contact between the ignimbrite and the underlying diamicton) (Fig. 7A), and by the formation of incisive channels at the passage junctions (Fig. 7B). This sector can be divided into three different subsectors based on their current hydrological function; we also identify two distinct levels in the cave A (upper level) and B (lower, presently active level).

Laguna Encantada (level $\mathrm{A}_{4}$ ): This is a small pond formed in the contact between the ignimbrite and the diamicton (Fig. 7C), and is highly decorated with different speleothems. The passage is approximately $8 \mathrm{~m}$ above the lower level, and is a relict from the first stage of the formation of the cave -in which the diamicton was not yet eroded, as it coincides with the inception level of the main cave (contact between diamicton and ignimbrite).

Salón de los Recuerdos (level $\mathrm{A}_{2}$ ): This passage presents a similar morphology to that of the level A; here it is possible to observe the initial stage of the development of the cave, consistent with the inception horizon and posterior incision of the river eroding the diamicton (Fig. 7D).

Tunel del Silencio (level $\mathrm{A}_{3}$ ): This section is currently non-active and its entrance is nearly blocked by flowstone. The passage has a phreatic morphology, elongated in the direction of the inception horizon. An incipient conduit, epiphreatic, is shown in the ceiling (Fig. 7E). The sediments in the roof only include backswamp facies.

Level B: Corresponds to the actual stream in the bottom of the cave, with incisive morphology eroding the diamicton (Fig. 7B). In the main room, the inception horizon is clear, and the incision of the river created a passage with keyhole morphology. Facies are similar to those described in sectors 1 and 2 . 

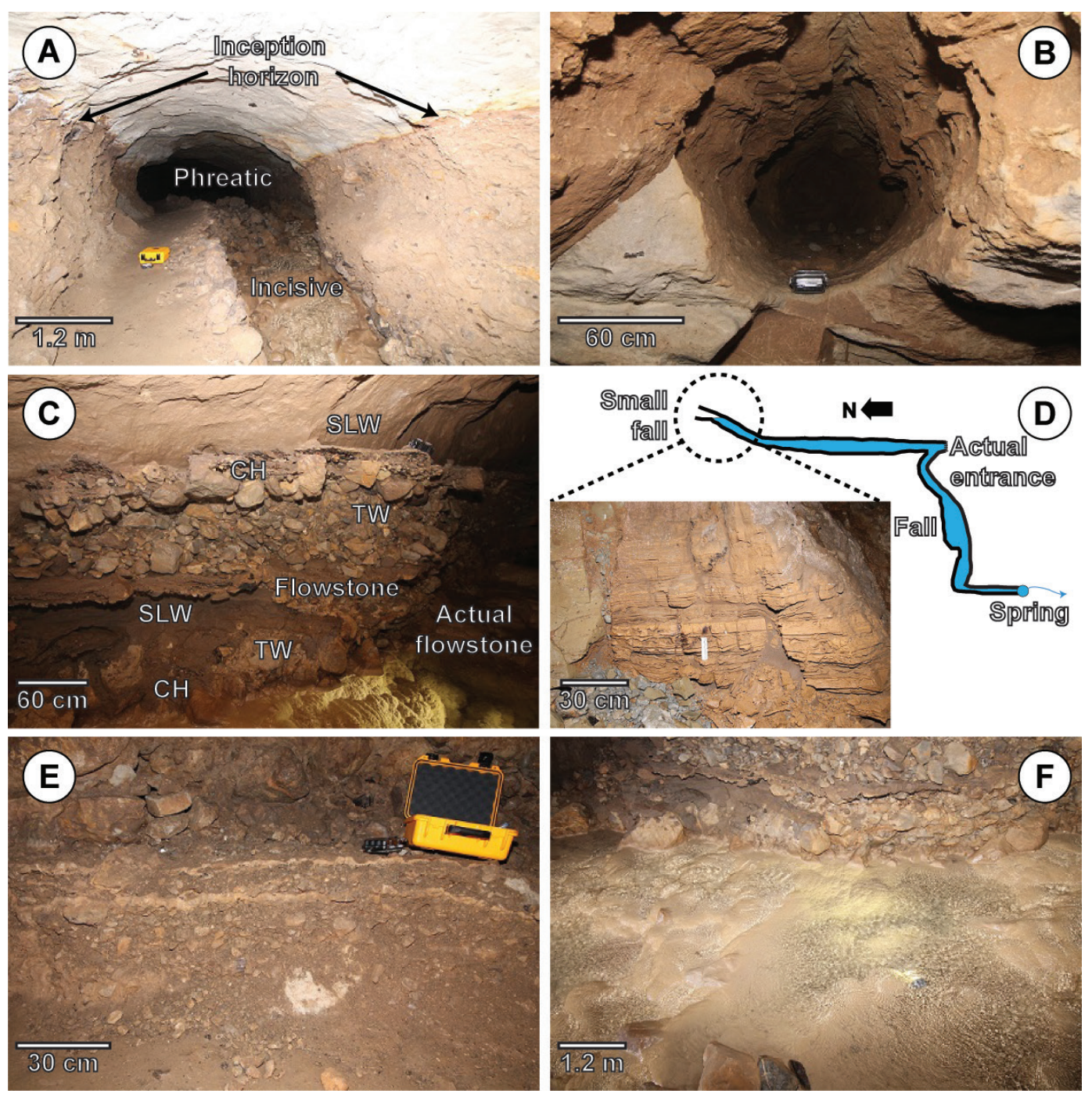

Fig. 6. Morphology at sector 3. A) Keyhole morphology within the passage, shows the elliptical phreatic morphology in the contact between the diamicton and the ignimbrite and an intrusive morphology that eroded the diamicton; B) Tributary phreatic conduits with circular cross section; C) Actual flowstone forming beside a sequence of sediments formed of channel facies, thalweg, slack-water deposits and old flowstone; D) Slackwater deposits close to a small waterfall located near a reduction in the diameter of the conduit; E) Clastic sequence intercalated with gaps of flowstone deposition; F) Present day flowstone formation.

\section{Geochemical characterization of the tuff}

The elemental composition of the ignimbrite at the Zapotitlán Quarry, together with previously reported data for the Xaltipan ignimbrite from Los Humeros Caldera (Ferriz \& Mahood, 1987; Willcox, 2012) and the Acoculco rhyolite (Verma, 2001) are shown in Fig. 8. The major element composition of the Zapotitlan Quarry tuffs shows that these are highly acidic, rhyolitic, with $\mathrm{SiO}_{2}$ contents ranging between 70 and $78 \%$ (Fig. 8A and Supplemental Table 3), and have similar compositions to those previously reported for the Xaltipan ignimbrite from Los Humeros Caldera and the Acoculco rhyolite. The REE composition for the ignimbrites (Fig. 8B) are all characterized by a significant enrichment of LREE over HREE (Supplemental Table 4), with $\mathrm{La} / \mathrm{Lu}=8.2 \pm 1.16$ (Ferriz \& Mahood, 1987; Verma, 2001; Willcox, 2012). However, the rhyolitic deposits from the Xaltipan ignimbrite show the most pronounced negative Eu anomaly $\left(\mathrm{Eu}^{*}\right), 0.19 \pm 0.16$, with other deposits from Los Humeros showing only slight Eu depletions. Fig. 8B shows the chondrite-normalized (McDonough \& Sun, 1995) $\mathrm{REE}_{\mathrm{N}}$ diagrams for the Zapotitlán Quarry and Los Humeros and Acoculco calderas rhyolites; and shows that both the Zapotitlán and Xaltipan ignimbrites have identical $\mathrm{REE}_{\mathrm{N}}$ composition, with La/ $\mathrm{Lu}=8.7 \pm 1$ ) and $\mathrm{Eu}^{*}=0.16 \pm 0.02$, while the Acoculco Caldera has a notorious lower $\mathrm{REE}_{\mathrm{N}}$ composition.

\section{Tuff and calcite geochronology}

The ${ }^{230} \mathrm{Th} /{ }^{232} \mathrm{Th}$ and ${ }^{238} \mathrm{U} /{ }^{232} \mathrm{Th}$ composition of the zircons extracted from the Zapotitlán Quarry ignimbrite is shown in Fig. 9A (Supplemental Table 5). In general, the zircons form two isotopically distinct groups: one in secular equilibrium plotting over the isoline (i.e., age $>350 \mathrm{ka}$ ), and a second group forming an isochron that yields an age of $168+7.7 /-7.5 \mathrm{ka}$. $(\mathrm{n}=8, \mathrm{MSWD}=0.95$, probability 0.47), and in perfect agreement with the U-Th composition of the magma. In Fig. 9A we also compare the U-Th composition of the zircons from the Zapotitlan ignimbrite with that from zircon grains extracted from a sample collected at Las Minas, Puebla $\left(19^{\circ} 41^{\prime} 32^{\prime \prime} \mathrm{N} 97^{\circ} 8^{\prime} 57^{\prime \prime} \mathrm{W}\right)$, which is generally recognized to be part of the Xaltipan ignimbrite (Ferriz \& Mahood, 1984). Both samples have identical compositions, providing strong evidence that the ignimbrite hosting the cave corresponds to the Xaltipan ignimbrite, emplaced $\sim 168 \mathrm{ka}$ ago as 

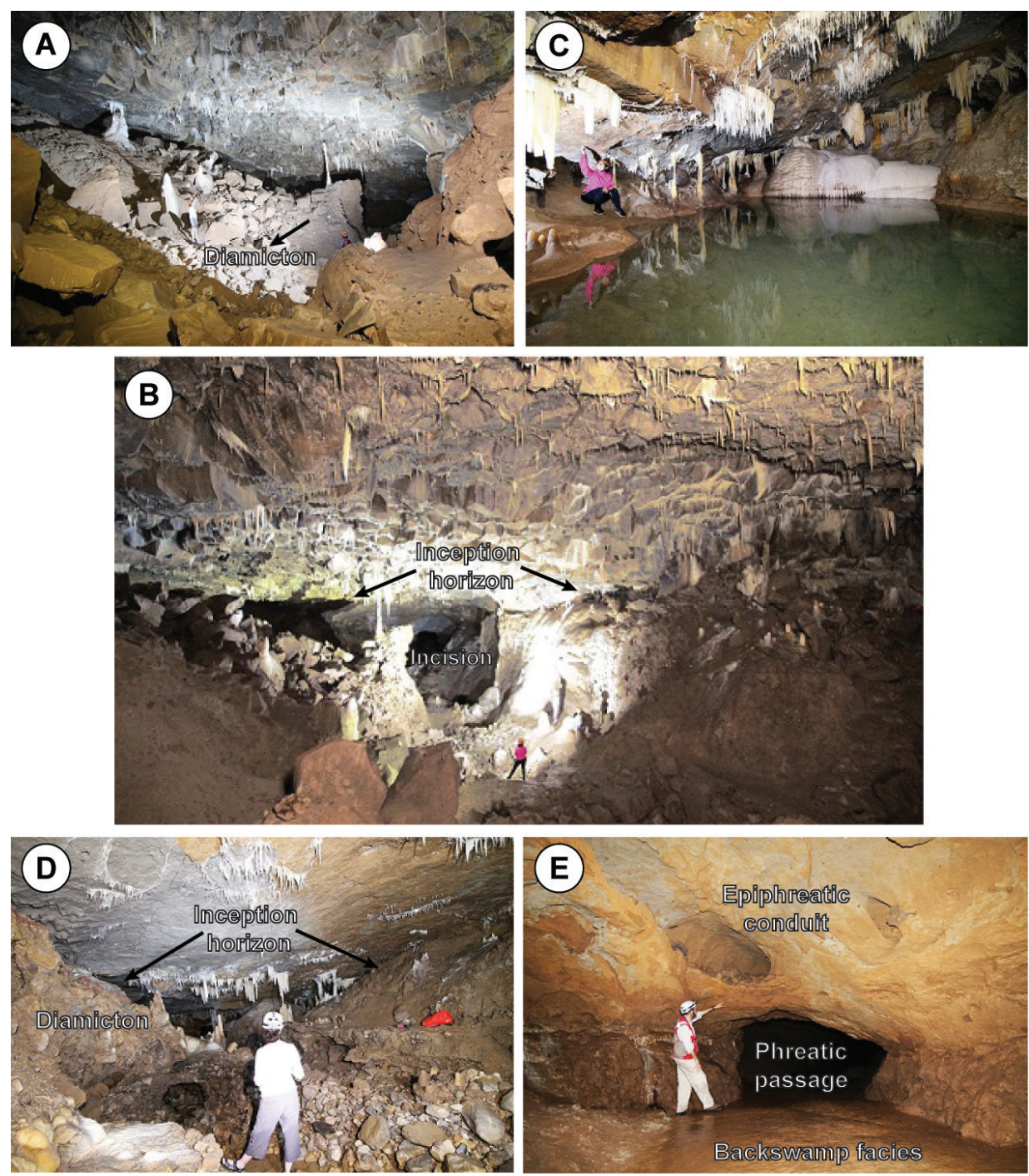

Fig. 7. Morphology at sector 4. A) The main chamber shows a near flat ceiling morphology and blocks of ignimbrite in the roof; B) The diamicton occupies most of the space between the actual roof and ceiling indicating the main process responsible for the passage grow is the erosion of the diamicton; C) At the Laguna Encantada the ceiling is inclined and resembles an ancient fissure-like in the direction of the deposition of the ignimbrite; D) At the Salón de los Recuerdos is possible to observe the inception horizon and posterior incision of the river eroding the diamicton; E) The Tunel del Silencio has a phreatic morphology elongated in the direction of the inception horizon and an epiphreatic conduit in the ceiling.

a result from pyroclastic flows associated with the collapse of Los Humeros Caldera. This result is in stark contrast to the previously K-Ar age of $400 \mathrm{ka}$ reported by Ferriz (1984), but in excellent agreement with more recent ${ }^{40} \mathrm{Ar} /{ }^{39} \mathrm{Ar}$ dating by Willcox (2012) who obtained an age of $170 \pm 50 \mathrm{ka}$ for basal fall of the Xaltipan tuff. The difference between the new results and the previously accepted age can stem from the presence of unrecognized inherited radiogenic ${ }^{40} \mathrm{Ar}$ in certain zones of the ignimbrite, a problem commonly found in volcanic tuffs with prolonged magma residence times (Bachmann et al., 2007; Phillips \& Matchan, 2013). These results provide quantitative evidence supporting previous interpretations by several authors that linked the origin of the ignimbrite at Zapotitlan to Los Humeros Caldera on the basis of volcanic stratigraphy (Capra et al., 2003; Lugo-Hubp et al., 2005; Hernández-Madrigal et al., 2007).

\section{Carbonate geochronology}

To obtain a minimum age for speleogenesis, we sampled and dated several flowstones found embedded between unconsolidated tuff or sediments. Because their occurrence generally implies the presence of voids where calcite-saturated water can degas $\mathrm{CO}_{2}$, leading to the precipitation of calcite, these are interpreted to represent the early stages for the system migrating from phreatic aquifer to the current vadose stage as a result from a drop in the local base level.

Unfortunately, most flowstone samples collected contained significant amounts of detrital material, with very low ${ }^{238} \mathrm{U} /{ }^{232} \mathrm{Th}$ ratios, hence hampering U-Th dating (Ludwig \& Paces, 2002), and only few samples proved amenable for dating with reasonably high ${ }^{238} \mathrm{U} /{ }^{232} \mathrm{Th}$ ratios, thus resulting in precise and meaningful ages (Table 1). The oldest flowstone sample (Fig. 9B), collected at the entrance of Sector 4, is sample KAR-fs-core which yields an ${ }^{230} \mathrm{Th}$-age of $95.6 \pm 2.1 \mathrm{ka}$. We interpret this result to represent a minimum age for the appearance of voids in the host rock where calcite can precipitate from the percolating solution and, thus, the minimum age for the phreatic-vadose transition sensu-stricto. Other 
(A)

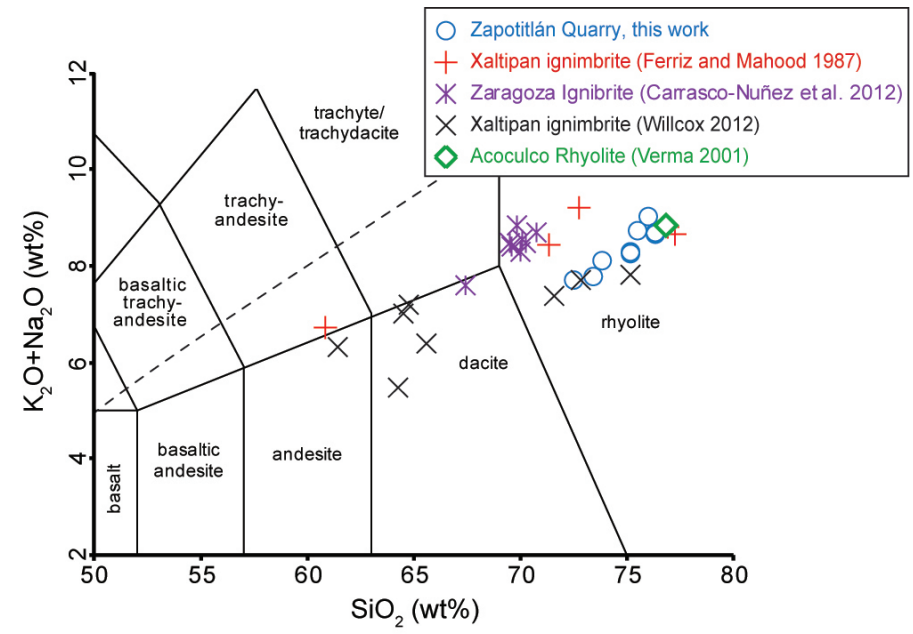

(B)

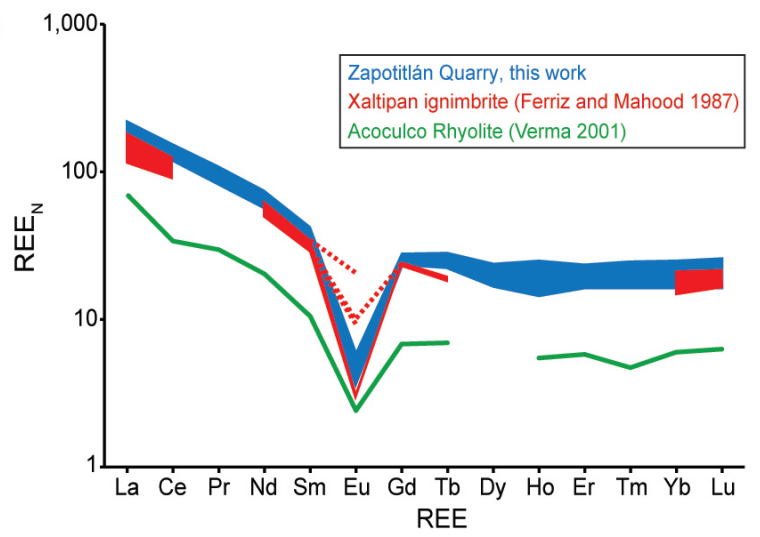

Fig. 8. Elemental composition of the Zapotitlán Quarry tuff (this work), the Xaltipan ignimbrite from Los Humeros Caldera and the Acoculco rhyolite A) Major element composition. Samples form Zapotitlán Quarry are shown in blue opened dots, data from Ferriz and Mahood (1987) in red crosses, Carrasco-Nuñez et al. (2012) in purple asterisks, Willcox (2012) in black crosses and Verma (2001) in green diamonds; B) Chondrite-normalized (McDonough \& Sun, 1995) REE (REEN) composition. Samples form Zapotitlán Quarry, blue, Ferriz and Manood (1987), red, Wilcox (2012), black, and Verma (2001), green. The different EuN values reported by Ferriz and Mahood (1987) are shown with red dotted lines.

flowstone samples collected nearby yielded ${ }^{230} \mathrm{Th}$ ages of $73.1 \pm 0.9$ and $52.1 \pm 0.7 \mathrm{ka}$ (Table 1).

The age of sample KAR-fs-core implies that carbonate speleogenesis in Las Karmidas Cave started only $70 \mathrm{ka}$ after the ignimbrite was emplaced. However, because of unavoidable sampling aliasing bias, where the age of a sample can be biased towards younger values due to the collection of different fractions with significantly different ages (e.g., Neymark et al., 2000; Paces et al., 2004), it is likely that KARfs-core might be somewhat older than the $95.6 \mathrm{ka}$ reported here. This suggests that the 70-ka period between the emplacement of the ignimibrite and the transition from phreatic to vadose proposed above, might only be a conservative value, and that the pseudokarstic process that generated Las Karmidas Cave could be significantly faster. In any case, this result attest for an extremely rapid evolution of this pseudokarstic system, and provides an insight on the rates of incision of the Zempoala River over the Xaltipan ignimbrite.

\section{Speleogenesis of Las Karmidas Cave}

Las Karmidas Cave displays a series of features that allow a well-supported speleogenetical reconstruction: well preserved conduit morphologies; good geochronological constraints; and well preserved clastic facies that provide information about paleohydrogeological evolution.

A simplified speleogenetical diagram of Las Karmidas Cave shows the main steps of cave formation (Fig. 10): firstly, deposition of the diamicton upon the hill slopes of the valley carved by the Zempoala River (Fig. 10A). During the caldera collapse event previously described (Ferriz \& Mahood, 1984), the valley was filled by pyroclastic flows that deposited the Xaltipan ignimbrite $168+7.7 /-7.5 \mathrm{ka}$ ago (Fig. 10B). The contrasting hydraulic conductivity between the recently deposited ignimbrite and the clay-based diamicton allowed for the transmission of meteoric water through the ignimbrite into the vadose zone, leading to the formation of a perched aquifer that flowed through the contact between the diamicton and the ignimbrite towards the discharge area and, consequently, forming the first phreatic conduits (Fig. 10C).

While the Zempoala River started to incise the new riverbed, the perched aquifer started to drain to the discharged area through the Tunel del Silencio $\left(\mathrm{A}_{3}\right)$. During this stage, cave evolution seems to have been mostly driven by piping, as suggested by the absence of channel and associated facies in this part of the cave (Fig. 10D). Lowering of the Zempoala River, and the increase of the hydraulic gradient, lead to the start of the incisive stage with the erosion of the diamicton, evidenced by channel and thalweg facies in
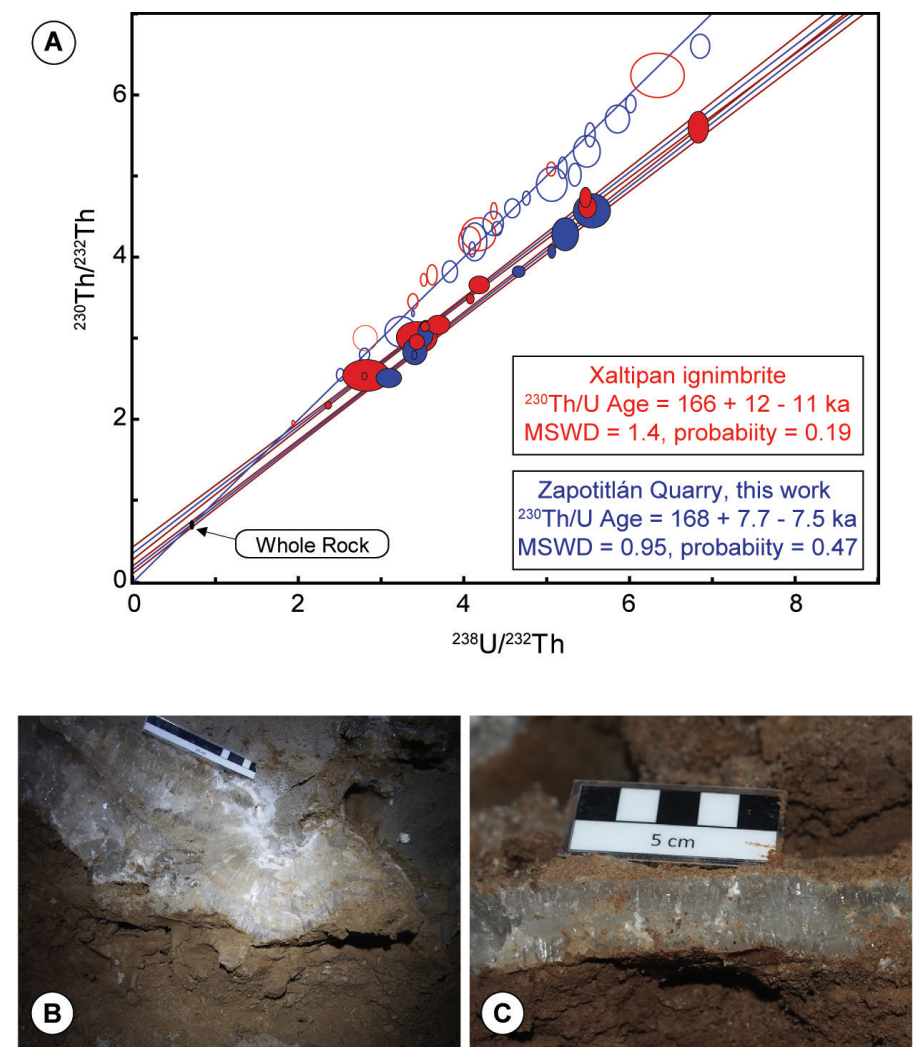

Fig. 9. Geocronology. A) ${ }^{230} \mathrm{Th} /{ }^{232} \mathrm{Th}$ and ${ }^{238} \mathrm{U} /{ }^{232} \mathrm{Th}$ composition of the zircons extracted from the Zapotitlán Quarry tuff (blue) and from a sample collected at location generally recognized as part of the Xaltipan ignimbrite (red); B) Carbonate flowstone KAR-fs-core, and C) Carbonate flowstone collected and dated. 
Table 1. Carbonates detrital-corrected U-series ages and compositions.

\begin{tabular}{|c|c|c|c|c|c|c|c|c|c|c|c|c|c|c|c|}
\hline & \multicolumn{8}{|c|}{ Measured } & \multicolumn{2}{|c|}{$\begin{array}{c}\text { Uncorrected } \\
\text { ages }\end{array}$} & \multicolumn{5}{|c|}{$\begin{array}{l}\text { Detrital-corrected age } \\
\text { and composition }\end{array}$} \\
\hline & $\begin{array}{c}\mathrm{U} \\
(\mathbf{p p m})\end{array}$ & \pm & $\delta^{234} \mathbf{U}$ & \pm & ${ }^{232} \mathrm{Th} /{ }^{238} \mathrm{U}$ & \pm & ${ }^{230} \mathrm{Th} / /^{238} \mathrm{U}$ & \pm & \begin{tabular}{c|}
${ }^{230}$ Th-age \\
(ka)
\end{tabular} & \pm & $\begin{array}{l}{ }^{230} \text { Th-age } \\
\text { (ka) }\end{array}$ & \pm & $\delta^{234} \mathrm{Uo}$ & \pm & $\rho$ \\
\hline Flowstone & 1.364 & 0.005 & 128.9 & 1.4 & 0.01708 & 0.00006 & 0.5647 & 0.0021 & 74.4 & 0.42 & 73.1 & 0.9 & 160.7 & 2.6 & -0.438 \\
\hline KAR-fs-core & 0.680 & 0.003 & 95.3 & 1.9 & 0.04008 & 0.00019 & 0.6602 & 0.0034 & 98.8 & 0.87 & 95.6 & 2.1 & 129.1 & 5.2 & -0.473 \\
\hline KAR-fs-sub & 0.919 & 0.004 & 209.2 & 1.6 & 0.01510 & 0.00006 & 0.4728 & 0.0020 & 53.2 & 0.3 & 51.2 & 0.7 & 245.5 & 2.6 & -0.493 \\
\hline
\end{tabular}
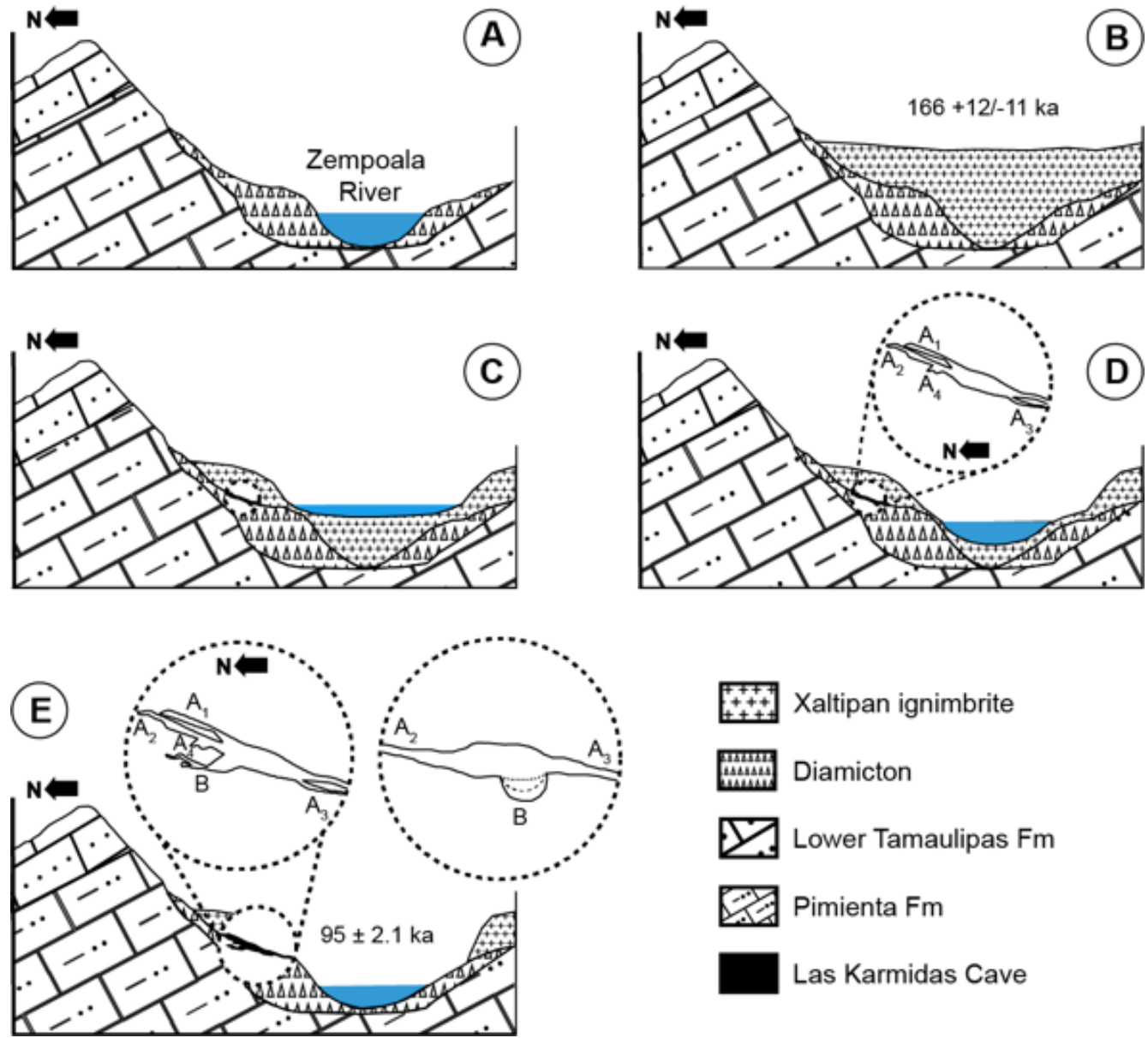

Fig. 10. Proposed Speleogenetic model for Las Karmidas Cave. A) The diamicton covered part of the valley carved by the Zempoala River within the Pimienta Formation; B) The valley was filled by the Xaltipan ignimbrite; C) The cave began to form within the contact of the diamicton and the ignimbrite while the Zempoala River eroded the valley again; D) The aquifer drained throughout the Tunel del Silencio $\left(\mathrm{A}_{3}\right)$;

E) As the Zempoala River eroded the valley, level B formed disconnecting level A.

sector $B$. This rapid erosion and entrenchment separated sectors A1, A2, and A3 from B, and led to the development of a main channel, as well as the abandonment of the higher levels (level A). At this stage, the hydrologic dynamics of the cave were substantially altered to a more direct and rectilinear discharge channel. Precipitation of carbonate speleothems started as soon as cave passages were partially drained.

\section{CONCLUDING REMARKS}

This study is the first report of a pseudokasrtic cave developed between ignimbrite and a diamicton, with calcite speleothems decoration. Its peculiarity allowed us to apply several geomorphological, sedimentological, geochemical and geochronological methodologies to establish a robust evolution model.

U-Th dating of zircon grains from the Xaltipan ignimbrite, in which Las Karmidas Cave is emplaced constrain the maximum age of the speleogenetical process at $168+7.7 /-7.5 \mathrm{ka}$, and is in perfect agreement with more recent ${ }^{40} \mathrm{Ar} /{ }^{39} \mathrm{Ar}$ dating. The inception horizon, located at the contact between the ignimbrite and the previously deposited diamicton, favored the formation of the earliest phreatic conduits forming the upper level. During this stage, piping initiated the enlargement of conduits, as suggested by the absence of high-energy facies deposits in this level. The lowering of the Zempoala riverbed changed the conditions from phreatic to vadose, with an important entrenchment of one preferable channel. At least in some parts of the cave, this initiated subaerial conditions and the precipitation of the oldest carbonates $(95.6 \pm 2.1 \mathrm{ka})$.

Considering the rather common geological context upon which Las Karmidas Cave evolved, it is likely that similar systems can be found elsewhere; however, due to very fast rate of evolution, long-term preservation in the stratigraphic record seems unlikely. 


\section{ACKNOWLEDGEMENTS}

The authors would like to thank the Editor Bogdan P. Onac, Paolo Forti, and two anonymous reviewers that kindly suggested improvements in the original text, their comments, suggestions, and constructive criticism lead to an improved manuscript. We also thank the people from Zapotitlán de Méndez (Puebla) for all their support and kindness. Special thanks to Herminio Rojas and his family, for facilitating access to the cave and helping us in any possible way; the Nieto Family, for their support and warm meals and shelter at the end of the day in the cave, and $\mathrm{Mr}$. Ernesto Manzano for granting access to the cave. We thank Elena Lounejeva, Rufino Lozano Santa-Cruz, and Carolina Muñoz Torres for analytical support, Bernardino Rodríguez (CGEO) for infrastructure support and maintenance, and Vicente Loreto, Miguel A. Hernández Patricio and Marisol Vega Orihuela for fieldwork support. This research was funded by projects CONACyT (grant \#78828); PAPIT / UNAM IN112008 and IN105713 (JPB) and National Geographic Society W418-15 (RLM). MPA-C was supported by a CONACyT scholarship \#61009. The authors would like to thank Dr. Gerardo Carrasco Núñez for kindly providing the Xaltipan ignimbrite sample from Las Minas, Veracruz.

\section{REFERENCES}

Alaniz-Álvarez S.A. \& Nieto-Samaniego Á.F. (Eds.), 2007 - Geology of México: Celebrating the Centenary of the Geological Society of México. Geological Society of America, 422: 465 p.

Audi G., Bersillon O., Blachot J. \& Wapstra A.H., 1997 The NUBASE evaluation of nuclear and decay properties. Nuclear Physics A, 624 (1): 1-124.

https://doi.org/10.1016/S0375-9474(97)00482-X

Bachmann O., Oberli F., Dungan M.A., Meier M., Mundil R. \& Fischer, H., $2007-{ }^{40} \mathrm{Ar} /{ }^{39} \mathrm{Ar}$ and $U_{-}$ $\mathrm{Pb}$ dating of the Fish Canyon magmatic system, San Juan Volcanic field, Colorado: Evidence for an extended crystallization history. Chemical Geology, 236 (1-2): 134-166.

https://doi.org/10.1016/j.chemgeo.2006.09.005

Benson R.C. \& Yuhr L.B., 2016 - Areas affected by karst and pseudokarst. In: Site characterization in karst and Pseudokarst Terraines: Practical Strategies and Technology for Practicing Engineers, Hydrologists and Geologists. Springer, Dordrecht, p. 41-43.

https://doi.org/10.1007/978-94-017-9924-9 5

Bernal J.P., Solari L.A., Gómez-Tuena A., Ortega-Obregón C., Mori L., Vega-González M. \& Espinosa-Arbeláez D.G., 2014 - In-situ ${ }^{230} \mathrm{Th} / U$ dating of Quaternary zircons using LA-MCICPMS. Quaternary Geochronology, 23 (10): 46-55.

https://doi.org/10.1016/j.quageo.2014.06.003

Bosch R.F. \& White W.B., 2004 - Lithofacies and transport of clastic sediments in karst aquifers. In: I.D. Sasowsky \& Mylroie J.E. (Eds.), Cave Sediments. Kluwer/Academic, New York, pp. 1-22.

Campos-Enriquez J. \& Garduño-Monroy V.H., 1987 The shallow structure of Los Humeros and Las Derrumbadas geothermal fields, Mexico. Geothermics, 16 (5): 539-554.

https://doi.org/10.1016/0375-6505(87)90038-1
Capra L., Lugo-Hubp J. \& Dávila-Hernández N., 2003 - Fenómenos de remoción en masa en el poblado de Zapotitlán de Méndez, Puebla: relación entre litología y tipo de movimiento. Revista Mexicana de Ciencias Geológicas, 20 (2): 95-106.

Carrasco-Núñez G. \& Branney M.J., 2005 - Progressive assembly of a massive layer of ignimbrite with a normalto-reverse compositional zoning: the Zaragoza ignimbrite of central Mexico. Bulletin of Volcanology, 68 (1): 3-20. https://doi.org/10.1007/s00445-005-0416-8

Carrasco-Núñez G., McCurry M., Branney M.J., Norry M. \& Willcox C., 2012 - Complex magma mixing, mingling, and withdrawal associated with an intra-Plinian ignimbrite eruption at a large silicic caldera volcano: Los Humeros of central Mexico. Bulletin of the Geological Society of America, 124 (11-12): 1793-1809. https://doi.org/10.1130/b30501.1

Cheng H., Lawrence Edwards R., Shen C.-C., Polyak V.J., Asmerom Y., Woodhead J., Hellstrom J., Wang Y., Kong X., Spötl C., Wang X. \& Alexander E. Calvin Jr., 2013 - Improvements in ${ }^{230}$ Th dating, ${ }^{230}$ Th and ${ }^{234} U$ halflife values, and U-Th isotopic measurements by multicollector inductively coupled plasma mass spectrometry. Earth and Planetary Science Letters, 371-372: 82-91. https://doi.org/10.1016/j.epsl.2013.04.006

Dickinson W.R. \& Lawton T.F., 2001 - Carboniferous to Cretaceous assembly and fragmentation of Mexico. Geological Society of America Bulletin, 113 (9): 11421160. https://doi.org/10.1130/0016-7606(2001)113 $\leq 1142:$ CTCAAF $>2.0 . \mathrm{CO} ; 2$

Doerr S. \& Wray R.A.L., 2004 - Paleokarst. In: Goudie A.S. (Ed.), Encyclopedia of geomorphology. Taylor \& Francis, London.

Eberhard R. \& Sharples C., 2013 - Appropriate terminology for karst-like phenomena: the problem with 'pseudokarst'. International Journal of Speleology, 42 (2): 109-113.

https://doi.org/10.5038/1827-806X.42.2.2

Eggins S.M., Woodhead J.D., Kinsley L.P.J., Mortimer G.E., Sylvester P., McCulloch M.T., Hergt J.M. \& Handler M.R., 1997 - A simple method for the precise determination of $\geq 40$ trace elements in geological samples by ICPMS using enriched isotope internal standardisation. Chemical Geology, 134 (4): 311-326. https://doi.org/10.1016/S0009-2541(96)00100-3

Ferriz H. \& Mahood G.A., 1984 - Eruption rates and compositional trends at Los Humeros Volcanic Center, Puebla, Mexico. Journal of Geophysical Research: Solid Earth, 89 (B10): 8511-8524. https://doi.org/10.1029/JB089iB10p08511

Ferriz H., 1985 - Zoneamiento composicional y mineralógico en los productos eruptivos del centro volcánico de Los Humeros, Puebla, Mexico. Geofisica Internacional, 24 (1): 97-157.

Ferriz H. \& Mahood G.A., 1987 - Strong compositional zonation in a silicic magmatic system: Los humeros, Mexican neovolcanic belt. Journal of Petrology, 28 (1): 171-209.https://doi.org/10.1093/petrology/28.1.171

Govindaraju K., 1994 - Compilation of working values and sample description for 383 standard reference materials. Geostandards Newsletter, 18 (2): 331.

Gray G.G., Pottorf R.J., Yurewicz D.A., Mahon K.I., Pevear D.R. \& Chuchla R.J., 2001 - Thermal and chronological record of syn-to post-Laramide burial and exhumation, Sierra Madre Oriental, Mexico. In: Bartolini C., Buffler R.T. \& Cantú-Chapa A. (Eds.), AAPG Memoir 75: The Western Gulf of Mexico Basin: Tectonics, sedimentary basins, and petroleum systems,. The American Association of Petroleum Geologists, p. $159-182$. 
Halliday W.R., 2007 - Pseudokarst in the 21st century. Journal of Cave and Karst Studies, 69 (1): 103-113.

Häuselmann P., 2011 - UIS mapping grades. International Journal of Speleology, 40: IV-VI.

Hernández-Madrigal V.M., Garduño-Monroy V.H. \& Alcántara-Ayala I., 2007 - Estudio geológico para entender los procesos de remoción en masa en la región de Zacapoaxtla, Puebla, México. Boletin de la Sociedad Geológica Mexicana, 59 (2): 147-162.

Hernández-Mendiola E., Bernal J.P., Lounejeva E., Mortimer G.E. \& McCulloch M.T., 2011 - U-series dating of carbonates using inductively coupled plasma-quadrupole mass spectrometry. Quaternary Geochronology, 6 (6): 564-573. https://doi.org/10.1016/j.quageo.2011.09.001

Hernández Z., 2008 - Mapa de susceptibilidad a procesos de remoción en masa con base en análisis multivariado: la región de Zapotitlán de Méndez, Puebla. Unpublished MSc Thesis, Universidad Nacional Autónoma de México, Querétaro, 106 p.

Jaffey A.H., Flynn K.F., Glendenin L.E., Bentley W.C. \& Essling A.M., 1971 - Precision measurement of halflives and specific activities of ${ }^{235} U$ and ${ }^{238} U$. Physical Review C, 4 (5): 1889-1906. https://doi.org/10.1103/PhysRevC.4.1889

López-Ramos E., 1979 - Geología general de México, 3, Mexico City.

López-Ramos E., 1982 - Geología de México, 3. Instituto de Geología, Mexico City.

Lozano R. \& Bernal J.P., 2005 - Characterization of a new set of eight geochemical reference materials for XRF major and trace element analysis. Revista Mexicana de Ciencias Geológicas, 22 (3): 329-344.

Ludwig K.R. \& Paces J.B., 2002 - Uranium-series dating of pedogenic silica and carbonate, Crater Flat, Nevada. Geochimica et Cosmochimica Acta, 66 (3): 487-506. https://doi.org/10.1016/S0016-7037(01)00786-4

Ludwig K.R., 2012 - Users manual for Isoplot/Ex. Ver 3.75, Berkeley Geochronology Center. Special Publication No. 1a, Berkeley, CA.

Lugo-Hubp J., Zamorano-Orozco J.J., Capra L., Inbar M. \& Alcántara-Ayala I., 2005 - Los procesos de remoción en masa en la Sierra Norte de Puebla, octubre de 1999: Causa y efectos. Revista Mexicana de Ciencias Geológicas, 22 (2): 212-228.

McCulloch M.T. \& Mortimer G.E., 2008 - Applications of the U-238-Th-230 decay series to dating of fossil and modern corals using MC-ICPMS. Australian Journal of Earth Sciences, 55 (6-7): 955-965.

https://doi.org/10.1080/08120090802097435

McDonough W.F. \& Sun S.-s., 1995 - The composition of the Earth. Chemical Geology, 120: 223-253.

https://doi.org/10.1016/0009-2541(94)00140-4

Müller W., Shelley M., Miller P. \& Broude S., 2009 Initial performance metrics of a new custom-designe ArF excimer LA-ICPMS system coupled to a two-volume laser-ablation cell. Journal of Analytical Atomic Spectrometry, 24: 209-214. https://doi.org/10.1039/B805995K

Neymark L.A., Amelin Y.V. \& Paces J.B., 2000 ${ }^{206} \mathrm{~Pb}^{230} \mathrm{Th}^{234} \mathrm{U}-{ }^{238} \mathrm{U}$ and ${ }^{207} \mathrm{~Pb}-{ }^{235} \mathrm{U}$ geochronology of Quaternary opal, Yucca Mountain, Nevada. Geochimica et Cosmochimica Acta, 64 (17): 2913-2928. https://doi.org/10.1016/S0016-7037(00)00408-7
Norini G., Groppelli G., Sulpizio R., Carrasco-Núñez G., Dávila-Harris P., Pellicioli C., Zucca F. \& De Franco R., 2015 - Structural analysis and thermal remote sensing of the Los Humeros Volcanic Complex: Implications for volcano structure and geothermal exploration. Journal of Volcanology and Geothermal Research, 301: 221-237.

https://doi.org/10.1016/j.jvolgeores.2015.05.014

Paces J.B., Neymark L.A., Wooden J.L. \& Persing H.M., 2004 - Improved spatial resolution for U-series dating of opal at Yucca Mountain, Nevada, USA, using ionmicroprobe and microdigestion methods 1. Geochimica et Cosmochimica Acta, 68 (7): 1591-1606.

https://doi.org/10.1016/j.gca.2003.08.022

Phillips D. \& Matchan E.L., 2013 - Ultra-high precision 40Ar/39Ar ages for Fish Canyon Tuff and Alder Creek Rhyolite sanidine: New dating standards required? Geochimica et Cosmochimica Acta, 121: 229-239. https://doi.org/10.1016/j.gca.2013.07.003

Schmitt A.K., 2011 - Uranium series accessory crystal dating of magmatic processes. Annual Review of Earth and Planetary Sciences, 39 (1): 321-349.

https://doi.org/10.1146/annurev-earth-040610-133330

Siebe C., Macías J.L. \& Aguirre-Díaz G.J. (Eds.), 2006 - Neogene-Quaternary continental margin volcanism: A perspective from México. Geological Society of America, 402: 329 p.

Solari L.A., Gomez-Tuena A., Bernal J.P., Perez-Arvizu O. \& Tanner M., 2010 - U-Pb zircon geochronology with an integrated LA-ICP-MS microanalytical workstation: Achievements in precision and accuracy. Geostandards and Geoanalytical Research, 34 (1): 5-18.

https://doi.org/10.1111/j.1751-908X.2009.00027.x

Verma S.P., 2001 - Geochemical evidence for a lithospheric source for magmas from Acoculco Caldera, Eastern Mexican Volcanic Belt. International Geology Review, 43 (1): 31-51.

https://doi.org/10.2747/1938-2839.43.1.51

Wiedenbeck M., Hanchar J.M., Peck W.H., Sylvester P., Valley J., Whitehouse M., Kronz A., Morishita Y., Nasdala L., Fiebig J., Franchi I., Girard J.P., Greenwood R.C., Hinton R., Kita N., Mason P.R.D., Norman M., Ogasawara M., Piccoli P.M., Rhede D., Satoh H., Schulz-Dobrick B., Skår O., Spicuzza M.J., Terada K., Tindle A., Togashi S., Vennemann T., Xie Q. \& Zheng Y.F., 2004 - Further characterisation of the 91500 zircon crystal. Geostandards and Geoanalytical Research, 28 (1): 9-39.

https://doi.org/10.1111/j.1751-908X.2004.tb01041.x

Willcox, C.P., 2012 - Eruptive, magmatic and structural evolution of a large explosive caldera volcano: Los Humeros, central Mexico, University of Leicester, Leicester, 326 p.

Wray R.A.L., 1997 - A global review of solutional weathering forms on quartz sandstones. Earth-Science Reviews, 42 (3): 137-160.

https://doi.org/10.1016/S0012-8252(96)00056-6

Yañez-García C. \& García-Durán S., 1982 - Exploración de la región geotérmica Los Humeros-Las Derrumbadas, estados de Puebla y Veracruz. Comisión Federal de Electricidad, 98 p. 